\title{
The Sport Nexus and Gender Injustice
}

\author{
Ann Travers, Simon Fraser University
}

Abstract: Male-dominated and sex segregated elite professional and amateur sport ${ }^{1}$ in North America constitutes a "sport nexus" (Burstyn, 1999; Heywood \& Dworkin, 2003) that combines economic and cultural influence to reinforce and perpetuate gender injustice. The sport nexus is an androcentric sex-segregated commercially powerful set of institutions that is highly visible and at the same time almost completely taken for granted to the extent that its anti-democratic impetus goes virtually unnoticed. The sport nexus's hegemonic role in defining sporting norms (Coakley \& Donnelly, 2004) means that its role in shaping lower level amateur and recreational sporting institutions and cultures is highly significant. Fraser (2007) defines gender justice, and hence democracy, in terms of "participatory parity," that is, material and cultural equality for women. The sport nexus itself is characterized by highly gendered occupational segregation (Coventry, 2004). It further contributes to gender injustice, homophobia and transphobia by promoting the ideology of the two sex system (Fausto-Sterling, 2000) and gendering citizenship as fundamentally male (Burstyn, 1999). Feminist strategies for sport reformation attempt to reduce or eradicate the role of the sport nexus in legitimating and perpetuating gender injustice. In this article I consider the potential of these strategies and conclude with a set of recommendations for transforming organized sport at both elite and recreational levels.

Fraser $(2007,2000,1997,1993,1987)$ has a long history of writing within the tradition of feminist political science/feminist theorizing on democracy and the public sphere (see also Pateman \& Mills, 2007; Pateman, 1989; Paxton \& Hughes, 2007; Barnes, Newman, \& Sullivan 2007; Conway, 2004; Young, 2000; Benhabib, 2004, 2002, 1996). Such feminist criticism of liberal-democratic theories and their supposed representation in western democracies is a wellestablished intellectual tradition. This work reveals that granting women de facto citizenship has not alleviated the problems resulting from the androcentric biases of liberal democratic theory and western democracy: the very role of citizen has been conceptualized and actualized as a male role (Pateman \& Mills, 2007; Pateman, 1989; Young, 2000).

In her most recent work, Fraser contributes the concept of "participatory parity" as a measure of gender justice (2007). She contends that gender justice is a condition of democracy defined by cultural equality (recognition) and material equality (redistribution) (2007, p.25). Gender injustice results when women are denied participatory parity by being culturally devalued and economically marginalized. For a society to be considered genuinely democratic, therefore, Fraser argues that women need to be culturally and economically included. As Fraser (2008, p.1) explains in a recent interview, gender justice, and hence democracy, requires

\footnotetext{
${ }^{1}$ At the World and Olympic level
} 
social arrangements that permit all members to participate in social interaction on a par with one another. So that means they must be able to participate as peers in all the major forms of social interaction: whether it's politics, whether it's the labour market, whether it's family life and so on. And parity of participation is quite demanding. It is not enough that there be simply the absence of legal discrimination; it means that you have all the effective conditions for really being able to participate.

The realm of sport in general and that constituted by the sport nexus, in particular, clearly qualifies as a "major form of social interaction." As such, conditions of participatory parity that are undermined in or by the sport nexus are incompatible with democracy.

The power of participatory parity as a measure of gender justice depends on the very definition of gender justice itself. If gender justice is defined in accordance with a narrow focus on women as an uncomplicated category, many of the failings of second wave feminism - to address the interlocking social forces of gender, race, class and sexuality (Lemert, 1999) - are likely to be replicated. Furthermore, without queer feminism's anti-essential reading of sex, gender and sexuality (Fausto-Sterling, 2000; Burke, 1996; Butler, 2004, 1990; Haraway, 1997, 1991), much of the role of the sport nexus in contributing to gender injustice will remain invisible. The ideology of the two sex system itself is centrally implicated in gender hierarchy and supports sexism, homophobia, and transphobia. The sport nexus normalizes and reinforces the ideology of the two sex system to the detriment of women, gays and lesbians and the non-normatively gendered (gender queer and transgender persons). A queer (anti-essential) approach to the concept of participatory parity and gender justice reveals the role of the sport nexus - elite male dominated sex segregated professional and amateur sport - in normalizing, legitimating and perpetuating the cultural and material marginalization of women and the non-normatively gendered.

Common sense views of sport - including its portrayal by mainstream media - tend to insulate the sport nexus from critical examination, whether by trivializing it - as merely entertainment, recreation or as a hobby for spectators - or valorizing it - as a grand expression of so-called national or universal values. In keeping with the critical tradition of Sport Sociology, I draw attention to the role of the sport nexus in promoting and perpetuating gender injustice through the cultural and economic marginalization of women and the non-normatively gendered. Much of the critical work on gender and sport that documents its role in reinforcing orthodox masculinity and perpetuating sexism, however, fails to challenge the sex segregated structure of sport itself. This structure is coercive and in itself represents gender injustice (McDonagh \& Pappano, 2008).

The role of the sport nexus in contributing to gender injustice includes the institution's powerful role in normalizing and legitimating the ideology of the two sex system (FaustoSterling, 2000). This ideology plays a significant cultural and economic role in the attendant devaluation of women, gays and lesbians, and transgender people. It is no accident that FaustoSterling's Sexing the Body (2000) begins with a devastating critique of gender verification (sex) testing at the highest levels of sport to establish the failure of science to demarcate boundaries between male and female bodies. The measuring of bodily capacity and limitations that the sport nexus is purportedly organized around underscores its significant cultural role in the hierarchical demarcation of both sex and race boundaries (Douglas \& Jamieson, 2006). That these socially 
generated boundaries are culturally understood as natural and unmediated by social forces makes them all the more unassailable.

\section{The Sport Nexus and Citizenship}

The sport nexus plays a significant role in gendering citizenship as male (and white and heterosexual). In her analysis of sport in western society as a "sacred rite," Canadian scholar Varda Burstyn (1999) documents the ways in which sport functions as a "men's club" that is used to consolidate male domination. Her specific claim is that sport solidifies masculine privilege and the related masculine subtext of citizenship and national identity. McDonagh and Pappano (2008) observe that American women's second-class citizenship in the world of sport translates into and mirrors women's second class citizenship in the nation itself. In contrast to such racially inadequate accounts of masculine privilege, however, there is evidence to suggest that African-American and African-Canadian male participation in the sport nexus may actually reinforce racist assumptions about black physicality and unintelligence thereby, somewhat ironically, perpetuating racism through inclusion (Hoberman, 1997; Abdel-Shehid, 2005). My focus in this article is on the antidemocratic role of the sport nexus in perpetuating gender injustice (the cultural and material devaluation of women and gender transgressors), through its role in celebrating hegemonic masculinity and normalizing the two sex system, thereby institutionalizing and reinforcing gender inequality, homophobia and transphobia.

The sport nexus genders citizenship as male by defining and reinforcing hegemonic masculinity and justifying (white, heterosexual) male supremacy (Connell, 1987; Anderson, 2005). In this role it complements and increasingly supplants the criteria of military service as a masculine qualifier for full citizenship (Mosse, 1988). In one of her earlier contributions, Fraser (1993) outlines the historical process whereby the role of citizen was conceptualized and actualized as a male role since it was ultimately dependent on an individual's ability to participate in political debate and, crucially, to defend his country in time of war. These qualities have been historically constructed as masculine rather than feminine (Fraser, 1987). While I grant the claim that Fraser and others make (Solaro, 2006; Feinman, 2000; Young, 2000) concerning the historical connection between masculinity, military service and citizenship, I contend that the role of the soldier and the military in embodying and celebrating orthodox masculinity in the west has declined considerably since the Vietnam war. This can be attributed to the public's awareness of the extent to which military forces are disproportionately made up of marginal rather than privileged members of the male population - in terms of class and race (Jeffreys, 2007) and the public's increasing skepticism about the justness of wars starting with Vietnam, then the Falklands, through to the two U.S. led campaigns against Iraq and Canada's military involvement in Afghanistan (Solaro, 2006).

The highly publicized and celebrated battles that men wage on the football field, the baseball diamond, on the basketball court and on the ice provide powerful pedigrees for male leadership in both sporting and non-sporting arenas. And not incidentally, the more closely a sport is tied to national identity, the greater the emphases are on its inherent masculinity and the need to erect barriers to female participation (Ring, 2008). For example, the sport of hockey is proclaimed by many to be "Canada's game." The Canadian men's hockey team victory over the Soviet Union in 1972 is understood as a defining moment in Canada's nationhood; former star hockey player 
Wayne Gretzky's celebrity status in Canada is much higher than that of any of the nation's political leaders (Whitson \& Gruneau, 2006). And in the United States where the sport of baseball is heralded as the "national pastime," legal challenges were necessary to enable girls to participate in Little League. Even so, Little League responded to the legal requirement to gender integrate by establishing a softball division and streaming girls into it (Ring, 2008; McDonagh \& Pappano, 2008). At the college level, efforts to resist gender equity requirements resulting from the passage of civil rights legislation (Title IX) culminated in the successful - but dubious achievement of a "contact sport" designation and hence exemption for baseball (Ardell, 2005).

With the exception of individual 'cheaters' who are caught using illegal performance enhancing substances, the heroic status of the successful male athlete and the appropriateness of the sport nexus for conferring such noble status are beyond mainstream reproach (Beamish \& Ritchie, 2003). The image of the white male or (good) black male athlete - Tiger Woods as opposed to Michael Vick - (Banet-Weiser, 2004; Zirin, 2007) as heroic warrior in the sport nexus (Burstyn, 1999) resonates historically, nationally (Miller, Lawrence, McKay \& Rowe, 2001) and symbolically to produce a gendered (and raced) cultural understanding of citizenship that denies women equal recognition. This has both cultural and economic consequences.

\section{The Sport Nexus and the Gender Binary}

While sport in North America (and much of the world) is organized around binary notions of biological difference between males and females (Kirby \& Huebner, 2002), queer feminist science and theory (Butler, 2004, 1990; Fausto-Sterling, 2000, 1992; Haraway, 1997, 1991) reveals the extent to which the taken-for-granted gender binary is as much constituted by assumptions about its existence as by the existence of distinctive and natural differences between only two sexes (Butler, 2004; Fausto-Sterling, 2000, 1992). Insights from postmodernism and queer feminist science have been incorporated into the literature on gender and sport to contribute powerful insights regarding the role of sport in normalizing and reinforcing the ideology of the gender binary and male supremacy (Pronger, 1990; Kane, 1995; Rothblatt, 1995; Theberge, 2000). The revelation that this two sex system is ideological rather than natural (Fausto-Sterling, 2000) underscores the role of sport in promulgating a vision of a stark biological divide between male and female bodies that is intricately bound up with gender injustice for women and gender transgressors throughout society. As Kane notes, the establishment of gender difference is a "product of patriarchal social construction" (1995, $\mathrm{p}$. 191). 'Male' and 'female' bodies are produced, in corporeal terms, in social contexts that assume and privilege male athletic competence at the expense of female physical development (Young, 1998; Pronger, 1990). The institutionalization of the two sex system as natural through the maledominated, sex segregated sport nexus contributes to the cultural and economic marginalization of women and gender transgressors in the world of sport itself and beyond.

The sport nexus not only demarcates hierarchical boundaries between men and women that resonate throughout society but plays a role in normalizing compulsory heterosexuality and gender conformity. This has powerful consequences for gays and lesbians, genderqueer and transgender people. Because of their equation with effeminacy, openly gay male athletes, or suspected gay male athletes, have been overtly discriminated against, harassed, and occasionally victimized by homophobic violence. No gay male participant in the elite levels of North 
American team sport has come out of the closet prior to retirement (Anderson, 2005); women athletes - regardless of their sexuality or personal tastes, for that matter - are routinely required to conform to orthodox heterosexual feminine norms in response to homophobia. For women, homophobia is a tool of sexism in restricting women's access to athletic development and participation in sport. Homophobia equates female athletic accomplishment with lesbianism. Thus, for men, the higher one's achievements in the sporting realm, the less suspicion there exists regarding homosexuality. In contrast, the more success a woman achieves in sport -with some differences depending on the sport - the more suspect her sexuality becomes (Griffin, 1998).

The sport nexus is no more a welcoming place for gender deviants than it is for gays and lesbians. Despite recent policy changes at the highest levels of organized sport to include postoperative transsexuals, the very investment of this policy in the two sex system closes doors. In 2003, the International Olympic Committee (IOC) adopted a policy to allow transsexual athletes to compete in their legal gender category provided they have been fully (surgically and hormonally) transitioned for two years prior to competing (BBC Sport, November 14, 2003). This policy serves to reinforce binary gender and preserve the assumption of male athletic superiority. Several scholars (Teetzel, 2006; Sykes, 2006; Cavanagh \& Sykes, 2006) have observed that institutional anxiety about transsexual participation in sport is for the most part limited to concerns about male to female transsexual athletes rather than female to male transsexual athletes. This anxiety rests on the taken for granted convictions that men and women are fundamentally different and that all males are athletically superior to all females. The predominant assumption of male athletic superiority that characterizes this "unfair advantage discourse" (Sykes, 2006) in sporting policy has a powerful hold on western consciousness. In spite of evidence that human variation is inconsistent with a two sex system (Fausto-Sterling, 2000) and failed attempts by the International Olympic Committee's medical commission to develop a definitive test for female athletes (Fausto-Sterling, 2000; Sykes, 2006), gender deviant athletes must achieve dimorphic physical and hormonal conformity or face exclusion. The sport nexus normalizes, legitimates and reinforces the ideology of the two sex system with marginalizing consequences for girls and women, gays and lesbians and gender transgressors within the world of sport and beyond.

\section{The Gendered Economy of the Sport Nexus}

Key sports in North American society are characterized by material (economic) gender injustice; but the role of these sports in celebrating masculinity and normalizing assumptions about female inferiority and the underlying ideology of the two sex system have a powerful cultural effect which in turn shapes economic opportunities. Sport plays an important role in normalizing gender inequality by emphasizing differences between male and female bodies to celebrate masculine superiority and by disproportionately rewarding male participants through extensive opportunity structures and disproportionate patterns of remuneration (Heywood \& Dworkin, 2003; Hall, 2002; Theberge, 2000; Burstyn, 1999). The fact that the names of professional women's sport associations need to be specifically gendered while men's remain unmarked (for example, Ladies Professional Golf Association vs. Professional Golf Association; Women's National Basketball Association vs. National Basketball Association) is a powerful example of 
the cultural assumption that sport is a male realm. Sport is simply assumed to be a male prerogative unless an exception is noted. The combination of its highly masculinist character and its importance in valorizing competition, hierarchy and nationalism (Coakley \& Donnelly, 2004) makes the sport nexus a key player in contributing to gender injustice.

A symbiotic relationship exists between elite sport and mainstream sports media to the extent that such sports media needs to be understood as an integral part of the sport nexus. Mainstream sport media play an important cultural and economic role in the sport nexus's celebration of masculinity through male sports and male athletes and the diminishment of women athletes and women's athletics (Walton \& Butryn, 2006; Messner, Dunbar, Hunt, 2000; Van Sterkenburg \& Knoppers, 2004). The role of sport media in making men's sports economic juggernauts underscores the relationship between economic and cultural social forces, the very dimensions that Fraser draws on in her definition of participatory parity. Studies of print and television media coverage of sport demonstrate the extreme marginalization of women's sport and women athletes (Messner et al., 2000; Van Sterkenburg \& Knoppers, 2004). When women's sports and women athletes are covered, they are far more likely to be sexualized than their male counterparts (Vincent, 2004). When women make progress in arenas typically identified as exclusively male, sexual representations are used to establish cultural boundaries that reproduce male supremacy (Birrell \& McDonald, 2000; Robinson, 2002). It is no accident that Danica Patrick's success in Formula One racing was coupled with a semi nude photo shoot in Sports Illustrated's hallowed (soft porn) "swimsuit edition" in 2008. This strategy for preserving male supremacy is borne out in a recent study (Kane, 2008) on the effect of sexist marketing strategies for women's sports. Kane found that the use of sexual objectification as a marketing tool, rather than building a greater fan base and greater interest in women's sports, actually undermines the female/pro-female (parents of girls, for example) fan base of women's sports while failing to generate a male fan base.

The economic gender injustice that characterizes key sports is evidenced in occupational segregation and pay inequity (Kay, 2003). Many of the most lucrative sports are sex segregated and exclusively male at the professional level (hockey, baseball, football). Where opportunities for women to play sport professionally do exist, significant pay inequity is the common condition. Ladies Professional Golf Association winnings fall considerably below (mens) Professional Golf Association winnings; only recently has the sport of tennis begun the practice of paying men and women equally. The example of pay inequity in the one major North American professional sport that has a women's league as well as a men's league is powerful. I provide below a comparison of National Basketball Association (NBA) and Women's National Basketball Association (WNBA) salaries. 
TABLE I: NBA VS. WNBA 2006/2007

\begin{tabular}{lll}
\hline & $\mathrm{NBA}^{*}$ & WNBA** \\
\hline Base Salary & $\$ 427,163$ & $\$ 30,000$ (rookies) \\
& & $\$ 42,000$ (veterans) \\
Maximum & $\$ 18,257,750$ & $\$ 79,400$ \\
Average & $\$ 4,500,000$ & $\$ 55,000$ \\
\hline
\end{tabular}

Notes:

* http://sportsillustrated.cnn.com/2006/basketball/nba/team.salaries/index.html

** http://www.nytimes.com/2006/05/19/sports/basketball/19wnba.html

This, of course, leaves out perks (NBA per diem of \$106 versus WNBA per diem of \$60) and sponsorship deals with advertisers (LeBron James ranks \#1 with a $\$ 90$ million deal over 7 years).

In an article in Forbes (www.forbes.com), on July 28, 2004, Kurt Badenhausen states that

The income inequality that exists between men and women isn't just taking place in the boardroom or on the factory floor-it's also taking place on the playing fields of profession-al sports. In the United States women only earn 77 cents for every dollar a man does. In the world of sports the gap is even bigger. The World's 50 Best Paid Athletes is the only Forbes list comprised entirely of men. The 50th highest-paid athlete over the past 12 months was basketball's Andre Miller, who made \$15 million. The top-paid female athlete during that time was Serena Williams, who earned $\$ 9.5$ million, followed by her sister Venus, who made $\$ 8.5$ million. The top-paid men: Tiger Woods and Michael Schumacher, who both banked $\$ 80$ million. You could put together a list of the 100 highest-paid athletes and still not find a woman on it.

In a 2006 update, the top paid male athlete for that year was Tiger Woods who earned $\$ 87$ million. The top paid female athlete in 2006 was Maria Sharapova who pulled in over \$20 in sponsorship deals in addition to her prize money from tennis tournaments (difficult to ascertain but probably not more than 3 million). Like Anna Kournikova, Sharapova's marketability relates largely to her physical appearance rather than to her feats on the court, even though she is far more accomplished than the former. Sharapova's stereotypical blonde beauty marks her as an appropriate object of male heterosexual desire (Crissey \& Crissey Honea, 2006; Stead, 2003) in contrast to the black noncompliance of the Williams sisters (Douglas, 2005) or the openly lesbian and heavily muscled Amelie Mauresmo.

\section{Feminist Strategies for Reforming the Sport Nexus}

Feminist strategies for reorganizing sport away from its role in promoting gender injustice fall loosely into four different approaches. In order to increase gender justice in and through sport we should: 
1. replace the current institutional structure of sport with non-competitive, non-hierarchical celebrations of physicality (radical feminist);

2. focus on and support elite women athletes as gender troubling figures and hence agents of change (third wave);

3. entirely eliminate sex as an organizational category (postmodern feminist); or

4. eliminate male-only sporting spaces while maintaining sporting spaces for girls and women (liberal feminist; queer).

I examine these strategies for their potential to increase participatory parity for women and gender transgressors and conclude with recommendations for reforming professional and amateur sport to achieve greater gender justice.

\section{We Should: Replace the Current Institutional Structure of Sport with Cooperative, Non-Hierarchical Celebrations of Physicality;}

Radical and cultural feminist scholarship shares the belief that "male supremacy and the subjugation of women [is] indeed the root and model oppression in society and that feminism[has] to be the basis for any truly revolutionary change (Donovan, 1987). It is up to feminists to model institutions and processes characterized by internal democracy - that is, shared decision-making in a nonhierarchical context (Heywood \& Dworkin, 2003). While not all of the authors I invoke here are necessarily inclined to identify as radical or cultural feminists, their critiques of the sport nexus and recommendations for change are highly consistent with this paradigm. These scholars (Burstyn, 1999; Pronger, 1999; Birrell \& Richter, 1987) indict sport in its current patriarchal capitalist iteration and seek to replace it with cooperative and nonhierarchical celebrations of physicality and play based on feminist principles of cooperation and inclusion. They seek sweeping changes to eliminate sports' endemic violence and hierarchical structure and call for new social institutions and practices that include and benefit everyone. Such an approach equates the competitive and hierarchical organization of sport with a destructive (orthodox) version of masculinity and advocates for feminist sport reformation away from hierarchy and competition and towards recreation, expression, play and cooperation.

Critics of the current masculinist, competitive, hierarchical model of sport do not necessarily see the recent increase in women's participation as a step toward gender justice (Suggs, 2005). From this perspective, Nike's recent "Just Do It" campaign aimed at women consumers is an encouragement to define gender equality as the ability to play with the boys - without questioning the rules of the game or its purpose. The rules of the game, however, are linked, at a fundamental level, to gender inequality, homophobia and transphobia.

Burstyn articulates a cultural feminist critique of sport as a men's club that consolidates male power and is thus anti-democratic. She makes a connection between masculine and corporate dominance of sport and advocates the de-masculinizing and de-corporatization of the sport nexus. Burstyn condemns "the 'sacrificial' nature of sport for both sexes" $(1999$, p. 275) and the brutality sport inflicts upon boys and men and models as appropriate social behaviour. She seeks a societal and institutional shift away from aggressive and competitive structures that harm both sexes and exclude many from participation to cooperative and physical recreation activities that involve and benefit the majority.

Advocating what I would term a postmodern cultural feminist approach to sport, Pronger (1999) views gender as a relationship rather than as an identity assigned to a body. This is 
significant in that he believes that women are as capable as men are of performing orthodox heterosexual masculinity. Pronger contends that sport promotes a specific and narrow form of masculinity: one that focuses on territorial expansion (penetration) and resistance to incursion: "The team whose desire produces the most invasive phallus, which is called offensive strategy, and tightest asshole, known as defensive strategy, wins the game" $(1999$, p. 382). While challenging essentialist notions of sex difference by viewing masculinity as a cultural construction that women can partake in, Pronger emphasizes the role of sports in normalizing the subjugation of women through the construction of "a set of binaries that emanate from the traditional homophobic construction of desire: winner/loser, top/bottom, dominant/submissive, phallus/asshole." These binaries, "have their fundamental logic in the patriarchal construction of masculine/feminine as the proper dispositions of men and women, respectively" (1999, p. 384). In the world of sport as it is currently practiced, Pronger observes, there are no "willing bottoms." He links this kind of performance to gender injustice and advocates for nonmasculinist and anti-homophobic sporting practices for everyone.

In tandem with feminist critiques of the sport nexus as fundamentally masculinist, cultural and radical feminist sport scholarship celebrates feminist possibilities for the transformation of sport (Birrell \& Richter, 1987; Lenskyj, 2003). Key feminist principles of sport include cooperation and shared power and decision-making (an end to hierarchical and competitive relations in sport - between players and between coaches and players); and the creation of an environment that emphasizes participation, inclusion, safety and joy over ability and winning. Such a cultural and radical feminist overhaul of sport would obliterate the sport nexus and much of amateur sport as we know it. In its place, I surmise that the varied recreational activities for people of all ages and walks of life typical of municipal Community Center programming would be expanded infinitesimally. ${ }^{2}$

\section{Prognosis for Gender Justice}

Condemning and seeking to transform aggressive/combative/hierarchical sporting places and practices as expressions of heterosexual masculinity embraces an essentialist view of nonegalitarianism as fundamentally masculine and therefore deleterious. Such a position is reminiscent of the sex wars of the 1980s that saw some feminists defining out of the movement so-called 'male-identified' women who advocated pro-sex, anti-censorship, S-M-embracing politics (Duggan \& Hunter, 1995). The institutional privileging of certain traits as inherently masculine or feminine - even if you believe, as Pronger (1999) does, that these traits can be performed by anyone - simply rearranges the terrain of gender injustice rather than reducing it. In addition, such an inadequately nuanced analysis of male power fails to address the dynamics of race and class (Carrington, 1998) that produce different relationships of privilege and inclusion - for women and for men. This oversight reflects an analysis of gender relations as the foundation of all oppression (Donovan, 1987); an analysis much-maligned by antiracist, queer and postmodern critiques of second wave feminisms (Hines, 2005; Heywood \& Dworkin, 2003).

\footnotetext{
${ }^{2}$ For example, http://vancouver.ca/parks/cc/mtpleasant/index.htm.
} 


\section{We Should: Focus On and Support Elite Women Athletes as Gender Troubling Figures and Hence Potential Agents of Change}

In response to the fracturing of the essentialist identity politics of feminism's second wave, particularly by antiracist, postmodern and queer critiques, a tradition of scholarship selfidentified as "third wave" emerged. Third wave feminism integrates postmodern, queer and antiracist deconstructions of essential identities and binary based epistemologies. According to Hines, "in third wave feminism, multiple female identity positions are recognized and attention is paid to the ways in which women's identities are constructed in relation to difference" (cited in Reger, 2005, p. 73). A third wave feminist perspective on sport and gender justice focuses on the role of the sport nexus in constructing women's identities and the potential of elite women athletes to resist and trouble stereotypical gender norms. (Heywood \& Dworkin, 2003).

Third wave feminists contest radical and cultural feminist arguments that view competition as a 'male' trait. Critical of gender essentialism, they view progressive and competitive physicality in sport as neither fundamentally male nor fundamentally bad. Not only should fiercely competitive and highly successful women athletes enjoy feminist legitimacy, they insist, but they should be valued for the powerful sociocultural role they play in the disruption of the gender binary (Heywood \& Dworkin, 2003).

Drawing on a Foucaultian analysis of oppression and activism that emphasizes resistance and refusal (Foucault, 1982), third wave feminism celebrates and promotes resistance to gender norms in and through the highly public setting of competitive sport as a mechanism for achieving greater gender justice. According to this perspective, by refusing and resisting rather than accepting and actualizing stereotypical gender norms, gendered power relations are inevitably altered. Far from viewing contemporary women athletes as being co-opted by a corporate, antifeminist nexus of domination as Burstyn does, or as performing, albeit ably, for Pronger, an oppressive masculine script, Heywood and Dworkin argue for the value and potential of Sport as "the Stealth Feminism of the Third Wave" (2003, p. 29). Stealth feminism celebrates the role of women athletes in actively resisting and refusing the ideology of the two sex system in particular and binary based epistemologies in general.

Much of the gender troubling potential of powerful women athletes rests on possibilities for media representation. A third wave feminist emphasis on representation directs critical attention to the role of mainstream sport media as part of the sport nexus in perpetuating a male dominated two sex system. In a highly influential article Kane (1995) argued that the gender binary paradigm in sport is grounded in biologically deterministic notions of gender polarity and features an emphasis on difference and the dismissal and deliberate invisibility of similarities between male and female athletes. This invisibility is essential for upholding male dominance and is achieved through the symbiotic relationship between mainstream sport and mainstream sport media (Kane, 1995, p. 191). Kane insists that a more accurate model for sport reporting portrays the gender continuum. A third wave feminist perspective celebrates the gender troubling leakages that are occurring in traditional sport media reporting as a result of women's participation. Coverage of women athletes whose performance flies in the face of assumptions of male athletic superiority undermines the ideology of the two sex system by making the gender continuum visible. 


\section{Prognosis for Gender Justice}

What is particularly powerful about this third wave strategy of focusing on and celebrating women athletes as gender troubling figures and hence potential agents of change is that it is already happening if only in a small way with the increasing visibility of powerful women athletes in North American society. We are seeing greater attention to gendered overlaps and performance - one has only to think of the Nike ads of the new millennium pitting a sweatsoaked Mia Hamm against Michael Jordan on a seemingly level playing field - even at the same time as male athletic superiority remains virtually taken for granted. Resistance is powerful: attention to gendered overlaps in performance has the potential to undermine assumptions about sex difference that rationalize gender inequality; the joy and empowerment that some girls and women experience and demonstrate in competitive athletics disrupts common sense assumptions about women, about sports, and about men. Glimpses of the gender continuum can be found in mainstream media coverage of "crossover athletes" (Roberts, 2005, p. 7) - elite women athletes who are competing in traditionally male only sporting contexts - and the occasional reporting of performance overlap between male and female athletes.

While Western history is replete with examples of women competing against men in sport, a postwar amnesia regarding this history seems to have taken hold (Ring, 2008; Hall, 2002). Even the explicitly feminist challenge to male dominance in sport and beyond made on the tennis court and in mainstream media by Billie Jean King in 1973 seems to have disappeared from cultural memory. Beginning in the early 1990s, seemingly without this historical precedent, a number of women have competed with and against men in typically male-only sporting arenas. Called "crossover athletes" by The New York Times, a term that continues to emphasize binary gender, these women include Manon Rheaume and Hayley Wickenheiser in hockey, Annika Sorenstam and Michelle Wie in the PGA, and Danica Patrick in Formula One Auto Racing. While most sports media coverage reinforces the status of these athletes as interlopers or mere spectacles, the cultural visibility of such women engenders third wave feminist excitement. There are also glimmers of doubt regarding male/female athletic performance gaps. Successful male athletes, such as Ernie Els of the PGA, have publicly stated their support for a gender integrated elite professional golf tour (Sportsnet Canada ${ }^{3}$ ), for example.

In its October 23, 2007 NBA Preview Issue, Sports Illustrated features a four page pull-out centerfold under the caption "Inch by Inch: The All-Time, All-Size All-Stars." asked "Who's the best at every height? Pro, college, men and women all included? Is it Bird or Magic? Elgin or Oscar? Shaq or Wilt? Calvin Murphy or Sue Bird?" This colourful centerfold displays a tallest to the smallest lineup of players who are purportedly the best ever by height. It begins at 7'7' with Manute Bol and ends at 5'3" with Mugsy Bogues. Both these players are men but the 5'8" slot is awarded to Sue Meyers, the 5'6" to Dawn Staley and 5'4" to Suzie McConnell. In addition to the three women who are identified as the best ever at their heights, 11 of the 72 runners up, listed under the winner of each height category, are women - starting at 6'4" and ending at 5'3". In this continuum-based showcase of the best North American basketball players of all time by height, out of 101 players listed, 14 are women. This is precisely the kind of sport journalism that third wave feminists are calling for - sport journalism that

${ }^{3}$ See http:www.sportsnet.ca

${ }^{4}$ Sport Illustrated. October, 23, 2007 
renders the gender continuum visible! Given the discrimination that girls and women experience in sport, it is rather incredible that more than 1 out of 10 of the best basketball players are women. We can only imagine what this centerfold might look like if potential female professional basketball players were sought out and nurtured to the same extent that male players are! The overlap between elite men and women players could only increase!

I share the third wave feminist sense of excitement and possibility in response to the increased visibility of powerful women athletes and I feel vindicated by evidence that some women dominate not just other women but the entire field as well. But while I grant the power of sports media coverage of gendered overlaps and performance, the gender troubling figure of the elite woman athlete championed by sport media continues to have a white and heterosexual subtext. A few individual women superstar athletes have emerged - notably soccer player Mia Hamm, thanks in large part to Nike's use of her image in an effort to increase its consumer base among women. Mia is a gender troubling figure in terms of stereotypes of feminine frailty but her cooptation has played a role in the selling of a new "beauty myth" (Wolf, 1992) for women that combines heterosexual femininity and a "six pack." She is white and heterosexual; a good girl. The absence of the black and powerful tennis superstar Williams sisters - often subjected to censure from sport media for uncorroborated poor sportsmanship (Douglas, 2005) - or openly lesbian Amelie Mauresmo in sport marketing speaks to the kind of gender troubling that will be tolerated.

\section{We Should: Entirely Eliminate Sex as an Organizational Category in Sport}

Queer postmodern feminism's deconstruction of the two sex system as ideological rather than natural (Fausto-Sterling, 2000, 1992; Haraway, 1997, 1991; Butler, 2004) supports an argument for the elimination of sex segregated sport. This argument can be summed up as follows: First, differences in men's and women's athletic performances can be attributed to social, political, economic, and psychological discrimination rather than biological factors. Given the cultural context within which athletes develop and perform, there is no uncontaminated data to support essential performance related differences between men and women (Pronger, 1990). Second, sport is implicated in translating the ideology of the two sex system into the material reality of bodies that conform to sexist expectations (Young, 1998). As such sport helps to mask the very gender diversity it plays such an important role in containing (Fausto-Sterling, 2000). Third, the very separation of girls from boys and women from men constitutes gender injustice. The legal reforms that require equal facilities and equal investment in sport and recreation opportunities and facilities for girls and women reinforce rather than diminish gender injustice. Rothblatt (1995) argues that just as racial segregation in sport has been abolished on the basis of the revelation that race is not meaningful as a biological category, so too should sex segregation. Drawing on the landmark court case Brown versus Board of Education 1954 to make the case that sex segregation is no more acceptable than racial segregation, Rothblatt states that "separate is never equal" (1995, p. 73). For these reasons, therefore, all levels of sport should be radically restructured to eliminate sex identity as a basis for organizing, separating or grouping individuals. For similar reasons, sex should be eliminated as an identifying category in government documents, in legal requirements for marriage, and as a basis for separate public facilities such as washrooms. In sport, this strategy would see the elimination of sex categories in all levels of competition. No sporting organizations would be closed to women and indeed all 
sporting organizations would be sex integrated - including those for girls and women. Sex identity would cease to be relevant as an organizing category or in terms of eligibility requirements.

\section{Prognosis for Gender Justice}

Such an across-the-board elimination of sex as a category for structuring sport might benefit a small minority of athletes currently categorized as girls and women possessed of an extreme degree of athletic ability, including the mental toughness required to play with and against men, many of whom can be expected to resist their inclusion. For a few of North America's most elite women athletes who are denied equal material opportunities and cultural rewards, such a restructuring could be unprecedentedly beneficial. Consider Canadian women's hockey superstar Hayley Wickenheiser, for example, or teenage golf phenom, Michelle Wie.

Hayley Wickenheiser is considered to be the best female hockey player in the world and her play in multiple Olympic Games has been dominant. While there is a long tradition of women playing hockey in North America (Theberge, 2000), opportunities have been scant in comparison to those available to boys and men. There is no professional women's hockey league to parallel the men's minor league system not to mention the National Hockey League and indeed no expectation that any will develop in the near future; only the establishment of women's ice hockey as a medal sport in the 1998 Olympics has created more (non-professional) opportunities for women. Where separate leagues for girls do not exist in Canada and the United States, girls have used the courts to gain the right to play on boys' teams (Theberge, 2000). Regardless of the increasing participation of women, hockey continues to be a male preserve (Adams in Whitson \& Gruneau, 2006). The identity of hockey as a sport is explicitly linked to Canadian masculinity and the NHL in particular is an "arena of masculinity" (Pronger, 1990). Wickenheiser broke ground and held her own among men as the first female player other than a goaltender to play in a men's professional hockey league when she played on a Swedish team for parts of two seasons in 2003 and 2004. She has just signed a contract to play for a third tier Swedish men's hockey team (Spencer, 2008, p. S5).

Michelle Wie provides another powerful example. In addition to her ability to drive a golf ball more than 300 yards - on par with many male golfers - Wie has made headlines and suffered scathing commentary from male and female players alike for playing both Professional Golf Association (PGA) and Ladies Professional Golf Association (LPGA) events (Millward, 2008) ${ }^{5}$. While she has not been particularly successful in PGA events - mostly failing to make the cut many of her male competitors have fared worse without experiencing criticism from media and fellow athletes for playing in the event at all. If professional golf ceased to be sex segregated and was organized, instead, by an ability-based (handicap) hierarchy, players like Wie would participate in tournaments they were able to qualify for. This would be a big step, at least in

\footnotetext{
${ }^{5}$ Most recently, in the July 30, 2008 edition of The Globe and Mail, LPGA legend and one time female interloper in a PGA tournament Annika Sorenstam, chastised Wie for forgoeing the LPGA British Open in favour of a PGA tournament. Sorenstam and other members of the LPGA tour have said that Wie should instead be learning to win on the women's tour, not attempting to qualify on the men's tour.
} 
formal terms, considering that several high-profile golf clubs in Canada and the United States continue to be restricted to men only.

Eliminating sex segregation entirely, however - including spaces and organizations reserved for girls and women - would constitute a major setback for the participation of girls and women in sport. Just because something is socially constructed - in this case, the two sex system with its assumption of female inferiority - does not mean it is not "real"; social forces have material consequences (Young, 1998; Lemert, 1999). Eradicating single-sex sporting spaces for girls and women without a prior cultural overhaul would mean that girls and women would be subjected to sexist and masculinist sporting cultures that discourage their participation. Rather than make visible the considerable overlap between sex categories and sporting outcomes, a sharp decline in female participation would reinforce cultural beliefs about sex differences and female inferiority. The tiny minority of elite women athletes who would flourish under such a restructuring would be so distanced from the majority as to be viewed as abnormal. Entirely eliminating sex as an organizational category in sport would result not in participatory parity and hence gender justice but in greater cultural and material marginalization. One potential advantage of this strategy, however, relates to transgender participation. The irrelevance of sex status would put an end to the contested and difficult social negotiation and assignment of individuals to the gender binary. There would be no need, for example, for an International Olympic Committee policy for transsexual participation or for transgender persons to produce official documents attesting to their sex category assignment. In this regard, then, a measure of gender justice might be achieved.

\section{We Should: Eliminate Male-Only Sporting Spaces While Maintaining Sporting Spaces for Girls and Women}

Going beyond the above strategy for eliminating sex as a basis for organizing all sport, this strategy makes a distinction between coercive and voluntary forms of segregation (McDonagh \& Pappano, 2008). It calls for an end to male-only sporting spaces while maintaining the right of girls and women to organize separately. The adoption of this strategy would require sporting spaces and institutions that are currently all-male to abolish formal and informal mechanisms for single-sex recruitment, development, participation, leadership and employment.

The strategy of pursuing greater gender justice by eliminating sex segregation in sport is consistent with a liberal feminist emphasis on individual rights, freedom from discrimimation and meritocracy (Madsen, 2000), values that are purportedly fundamental to western democracies. The abolition of sex segregation in sport at both the highest levels and in many recreational contexts is required to achieve the formal gender equality - enacted thus far through occupational and human rights measures outlawing sex discrimination - that western nations take such pride in (Ware, 1992). An absolute end to discrimination in sport is yet another step in ensuring that merit, not ascription, determines opportunity and reward structures. The discrimination against women codified in professional and amateur sport policy and institutions is one of the last legal frontiers in the struggle against sexist discrimination. In an interesting parallel, liberal feminists have advanced similar arguments to justify the full inclusion of women in the military - including combat roles (D'Amico \& Weinstein, 1999). A rights-based liberal feminist approach includes affirmative action measures to address inequalities in abilities that result from long term discrimination. McDonagh and Pappano (2008) call for an end to sex 
segregation in sport with the proviso that single-sex sporting spaces be retained for girls and women: "all sports competitions should be based on the abilities of the individuals who seek to play, not on stereotypical attributes of sex or race groups. The only exception...is voluntary segregation for a subordinate group in order to compensate for past discrimination" (McDonagh \& Pappano, 2008, p. 28)

This liberal feminist emphasis on meritocracy supports an analytical parallel between sex segregation and racial segregation and their eradication as a necessity for social justice. McDonagh and Pappano (2008) claim that the coercive nature of sex segregated sport in North America is an injustice and must be abolished. Coercively sex segregated sport makes women second class citizens off the field and fails to reflect actual physical differences between the sexes. McDonagh and Pappano draw on the same U.S. legal decision - Brown vs. Board of Education, 1954 - that Rothblatt does as noted above to assert similarities between racial and sex segregation. The forced separation of girls and boys and women and men is related to gender inequality; the very assumption of difference amounts to injustice. This strategy for reducing gender injustice requires an end to the social, political and legal tolerance of sex discrimination that characterizes North American sport today. But the abolition of sex segregated sporting spaces and institutions should not extend to those organized as single-sex spaces for girls and women. As a subordinate group, girls and women should be able to "choose participation on either a sex integrated or voluntary sex segregated basis" (McDonagh \& Pappano, 2008, p. 80). From this perspective, voluntary segregation aimed at increasing group standing is an acceptable social practice for minority groups but not for dominant groups.

\section{Potential for Gender Justice}

While gender inequality persists in Canada and the United States, civil rights-based challenges to occupational segregation have eliminated most legal barriers to the full participation of women in all aspects of society (Matthews \& Beaman, 2007; McDonagh \& Pappano, 2008). And some of the major barriers to the full participation of girls and women in (mostly amateur, that is, nonfinancially remunerative) sporting activities have been removed (Yurako, 2002). But while legal challenges have resulted in the integration of some sporting spaces (Little League Baseball, for example, Ring, 2008; McDonagh \& Pappano, 2008), most coercively sex segregated sporting spaces remain a taken for granted fact of life. Title IX - the most significant civil rights legislation relating to the participation of girls and women in sport in the United States amounts to both a step forward and a step backward in the fight for gender justice in sport and beyond. Title IX's requirement that federally funded institutions and programs offer equal access and opportunity to girls and women has contributed to gender justice by recognizing girls and women as athletes and providing institutional structures for their sporting activities (Cooky \& Macdonald, 2005). In spite of considerable increases in the participation of girls and women in sport following the signing into law of Title IX, however, this legislation continues to reinforce and promote gender injustice for girls and women by emphasizing the distinct and inferior status of women athletes. According to McDonagh and Pappano (2008), this is because the ultimate impact of Title IX was to normalize female inferiority rather than to promote real gender justice. While they acknowledge that Title IX "was important, even critical.... it unfortunately reinforced-rather than challenged-the belief that women are inherently inferior to men" (p. 223). 
Abolishing single-sex sporting spaces for boys and men while maintaining them for girls and women would increase gender justice in sport and beyond in several ways. First, it would send a clear message through legal stipulations preventing male only policies and practices that sexist discrimination directed at girls and women is no more tolerable than racist discrimination directed at people of colour. Gender integrating the sport nexus would put an end to the last formal institutional frontier for enacting and showcasing sexist discrimination. This would have powerful positive cultural and material consequences for the status of women. Secondly, allowing girls and women to learn sport and compete with boys and men would improve their athletic ability, thereby lessening the culturally produced disadvantage that is the product of sexist discrimination. McDonagh and Pappano (2008) cite educational research that demonstrates the performance improvement of disabled students in integrated - that is, nonsegregated - classroom environments to draw a parallel with the merits of sex integration. They insist that enabling girls and women to compete with boys and men in sport will increase female performances. Thirdly, this strategy for reducing the role of the sport nexus in perpetuating gender injustice would maintain important single-sex opportunities for girls and women that are necessary as long as their minority status persists. This strategy's distinction between coercive and voluntary segregation supports the abolition of one and the maintenance of the other in a manner that is consistent with Rawls' (1999) 'difference principle' for social justice, according to which discrimination is considered acceptable only when it reduces the marginalization of disadvantaged groups in society. The current male-dominated, sex segregated sport nexus maintains the status quo of gender injustice; forcing gender integration of this institution would be a step towards attaining participatory parity for women.

The potential of this strategy for increasing gender justice in sport and beyond requires attention to a few challenges. First, maintaining single-sex sporting spaces for girls and women may perpetuate gender injustice if these spaces adopt binary based policies for inclusion. Second, where sporting spaces are currently gender integrated, many are characterized by a climate of sexism and misogyny that keeps all but the bravest and almost freakishly talented girls and women from participating. As mentioned before, Little League Baseball responded to legal requirements to include girls by developing a program of Little League Softball and streaming girls into it (Ring, 2008; McDonagh \& Pappano, 2008). It took more than 25 years after that for a girl to actually participate at the highest level of Little League baseball in the 2005 Little League World Series (About.com:Baseball). And, in an attempt to break out of a recent batting slump, members of the Chicago White Sox Major League Baseball Team used their bats to symbolically rape a blow up doll in their locker room (Sportsnet Canada). Many male-only sporting spaces are sexist, misogynist and homophobic; harsh informal resistance to gender inclusion can be expected. It is not just that so many of the spaces of the sport nexus are male only; they tend to be fundamentally misogynist, homophobic and transphobic as well. Abolishing formal barriers to the participation of women cannot be assumed to address this foundational component of sport. Furthermore, to take up the parallel between racial and gender segregation in sport that Rothblatt and McDonagh and Pappano draw: desegregation does not necessarily reduce social injustice. Hoberman's (1997) indictment of the role of racially desegregated sport in perpetuating racism suggests that just as racism has been accomplished through inclusion (emphasis on black physicality over intellect; invisibility of blacks who are not athletes, entertainers or criminals; drawing black youth away from the classroom and onto the sportsfield; the illusion that desegregation means that racism is a problem of the past) sexism and 
gender injustice may morph and survive through inclusion. Danica Patrick's recent Formula One racing success and concurrent sexualization suggests this possibility.

In addition to these concerns there are the inherent problems associated with liberalism's celebration of meritocracy as the ultimate expression of democracy. Fraser's concept of participatory parity incorporates an economically socialist dimension in its indictment of hierarchy as inconsistent with democracy. I suggest that combining a queer feminist suspicion of the naturalness of all bases of hierarchy (Fausto-Sterling, 2000; Haraway, 1997, 1991) with Fraser's standard of participatory parity has the potential to sufficiently radicalize the liberal feminist basis of this fourth strategy to increase its inclusive potential. Fraser's concept of participatory parity as a measure of gender justice complements queer feminist science's deconstruction of the two sex system as ideological and provides a powerful mechanism for the indictment of the sport nexus as anti-democratic. Sport, like other social institutions that operate to privilege some members of society while marginalizing others, must be transformed away from binary-based biological epistemologies that privilege white corporate masculinity. Applying a queer feminist turn to this strategy for reducing gender injustice by eliminating coercive segregation in sport ensures that the struggle for gender justice includes not only women and girls but gays, lesbians and gender transgressors as well. This makes it possible to generate both concrete, justifiable structural and procedural changes to sport institutions and practices, while retaining sufficient open-endedness to push for ever-increasing parity for all participants. Below is a list of recommendations for institutional change that begin to provide a vision of this approach's power for change:

\section{Recommendations}

\section{The Sport-Nexus and Sport Media}

- Eliminate legal protection for male only professional sporting spaces;

- Require all levels of sport to conform to occupational human rights standards relating to non-discriminatory practices with regard to development, recruitment and promotion.

- Provide women and transgender persons with the option of sharing the general locker room with men or utilizing an equally equipped separate space while ensuring that formal team meetings and discussions are conducted in an inclusive space.

- Adopt a zero tolerance policy for racism, sexism, homophobia and transphobia with consistent and meaningful consequences for violations;

- Consider and grant requests for government accreditation and support only for sporting organizations that demonstrate compliance with human rights requirements relating to the inclusion of women and gender transgressors;

- Grant and renew broadcast licenses only to organizations that demonstrate a commitment to gender justice in their organizational structure and in all aspects of sports coverage.

\section{Amateur Sport}

- Eliminate legal protection for male only sporting spaces at all levels of sport; 
- Provide women and transgender persons with the option of sharing the general locker room with men or utilizing an equally equipped separate space while ensuring that formal team meetings and discussions are conducted in an inclusive space.

- Adopt a zero tolerance policy for racism, sexism, homophobia and transphobia with consistent and meaningful consequences for violations;

- Require amateur sport at all levels to invest equal resources into the recruitment, development and support of male and female athletes;

- Certify and provide public facilities exclusively to amateur sporting associations that require all leadership personnel to undertake formal accredited training relating to gender justice in sport.

- Allow and support organizations for girls and women only;

- Require such organizations to adopt trans-inclusive policies (Travers, 2006).

\section{The Sport Nexus: As Solid as the Berlin Wall}

The abolition of sex-based structural barriers to the participation of girls and women is, arguably, only a few court cases away. Legal challenges have already resulted in the ability of girls to play on boys' teams when no girls' teams are available and even when there are (less competitive) girls' teams available. In contrast, boys' efforts to play on girls' teams have failed (McDonagh and Pappano, 2008). This indicates that lower courts in the United States seem to have distinguished - at least implicitly - between coercive sex segregation as sexist discrimination and voluntary sex segregation for girls and women as a partial, legal remedy for decades of discrimination. These legal challenges have begun to alter the structure of amateur sport but this process will not be complete until a pivotal case or two reaches the highest courts and - to parallel the impact Brown vs. Board of Education 1954 had on the formal structure of racism results in an end to the structure of legal sex discrimination. The legal erosion of institutional gender injustice in amateur sport will inevitably ripple up to professional sport at all levels.

Increased opportunities for girls and women to participate in sport and the emergence of powerful women athletes - both those who excel in women's sport and those who "cross over" have created fertile ground for pivotal legal challenges to male-only sporting spaces. The celebration of girls and women as athletes represents a cultural shift. This shift is generating a powerful group of pro-girl allies in the quest to end at least some facets of gender injustice in sport. Importantly, these allies include parents of girls and women - a small but astute percentage of "soccer moms" and hockey dads who are angered by sexist discrimination against their daughters and are willing and able to use the courts to fight back.

Challenging as it is, changing the sexist structure of sport is relatively easy compared to the difficulty of transforming the entrenched mysoginist, homophobic and transphobic culture of sport and sporting spaces. After all, the inclusion of men of colour in formerly white, male sporting spaces has only partially changed the culture and material consequences of racism in sport and beyond and not necessarily in ways that decrease racial injustice. Gay men participate in sporting spaces through amateur to elite levels but often pay the price of secrecy, fear and sexist and homophobic collusion in order to do so. It is entirely valid, therefore, to criticize liberal feminist strategies aimed at achieving legal change for failing to provide means for altering the culture of gender injustice that is foundational to male-dominated sporting spaces. 
Merely including girls and women in these spaces is insufficient to accomplish this. And yet, the cultural power of inclusion is never insignificant as it provides a basis of legitimacy for further social justice initiatives.

The shake-up of sport I propose is incredibly radical and yet consistent with the democratic norms North Americans so ardently codify and pay lipservice to. It is this consistency that creates an opening for legal challenges to achieve at least some of the above recommendations. As a result, it is not as impossible as it seems. As history has shown, significant institutional social change is never out of the question. For example, African Americans in the United States have used democratic ideology to de-legitimize racism through legal challenges and the achievement of civil rights legislation that prohibits racism. Heroically fought for, this Civil rights legislation has had an impact: racial inequality remains a fact of life but racism is disavowed and formal barriers to equality have been eliminated (Morris, 1984). The 1947 racial integration of Major League Baseball that is so celebrated - and taken for granted - by the sport today was bitterly resisted at the time and for more than a decade after (Lapchick, 2001). While many people never expected same-sex marriage to be legalized in Canada, homophobia persists and same sex marriage is but one component of efforts to reduce it. This legal victory provides increasing legitimacy to struggles against homophobic gender injustice. The sport nexus contributes significantly to gender injustice but its ability to do so will be eroded as the legality of its practices of exclusion is contested. 


\section{References}

Abdel-Shehid, G. (2005). Who Da Man? Black Masculinities and Sporting Cultures. Toronto: CanadianScholars' Press Inc.

About.com: Baseball http://baseball.about.com/od/youthbaseball/p/llws.htm

Anderson, E. (2005). In the Game: Gay Athletes and the Cult of Masculinity. Albany, NY: State University of New York Press.

Ardell, J.H. (2005). Breaking into Baseball: Women and the National Pastime. Carbondale, IL: Southern Illinois University Press.

Badenhausen, K. (2004). Uneven Playing Field. Forbes (www.forbes.com), July 28, 2004. http://www.forbes.com/lists/2004/06/28/cz_kb_0628gender.html

Banet-Weiser, S. (1999). Hoop Dreams: Professional Basketball and the Politics of Race and Gender. Journal of Sport \& Social Issues, 23(4), 403-420.

Barnes, M., Newman, J. \& Sullivan, H. (2007). Power, Participation and Political Renewal: Case Studies in Public Participation. Bristol, UK : Policy Press.

Beamish, R. \& Ritchie, I. (2005). Sport in History. London: Routledge.

BBC Sport (2003). Transsexuals Get IOC Hope. Retrieved on November 14, 2003 from http://news.bbc.co.uk/sport2/hi/front_page/3270591.stm.

Benhabib, S. (2004). The Rights of Others: Aliens, Residents and Citizens. Cambridge, New York: Cambridge University Press.

Benhabib, S. (2002). The Claims of Culture: Equality and Diversity in the Global Era. Princeton, N.J: Princeton University Press.

Benhabib, S. (Ed.). (1996). Democracy and Difference: Contesting the Boundaries of the Political. Princeton, N.J: Princeton University Press.

Birrell, S. \& McDonald, M.G. (2000). Reading Sport: Critical Essays on Power and Representation. Boston: Northeastern University Press.

Birrell, S. \& Richter, D. (1987). Is a Diamond Forever? Feminist Transformations of Sport. Women's Studies International Forum, 10 (4), 395-409.

Burke, P. (1996). Gender Shock. New York: Double Day.

Burstyn, V. (1999). The Rites of Men: Manhood, Politics and the Culture of Sport. Toronto, Ontario: University of Toronto Press.

Butler, J. (1990). Gender Trouble: Feminism and the Subversion of Identity. New York and London: Routledge.

Butler, J. (2004) Undoing Gender. New York: Routledge.

Carrington, B. (1998). Football's Coming Home. But Whose Home? And Do We Want It? Nation, Football and the Politics of Exclusion. In A. Brown (ed.), Fanatics! Power, Identity and Fandom in Football (pp. 101-123). London: Routledge.

Cavanagh, S. \& Sykes, H. (2006). Transsexual Bodies at the Olympics: The International Olympic Committee's Policy on Transsexual Athletes at the 2004 Athens Summer Games. Body and Society, 12 (September), 75-102.

Coakley, J. \& Donnelly, P. (2004). Sport and Society: Issues and Controversies. Toronto: McGraw-Hill Ryerson.

Connell, R.W. (1987). Gender and Power: Society, the Person and Sexual Politics. Cambridge: Polity Press.

Conway, J. M. (2004). Identity, Place, Knowledge : Social Movements Contesting Globalization. Halifax, N.S: Fernwood.

Cooky, C. \& MacDonald, M. (2005). If You Let Me Play: Young Girls' Insider-Other Narratives of Sport. Sociology of Sport Journal, 22 (2), 158-177. 
Coventry, B. (2004). On the Sidelines: Sex and Racial Segregation in Television Sports Broadcasting. Sociology of Sport Journal, 21 (3), 322-341.

Crissey, S. R. \& Honea, J.C. (2006). The Relationship between Athletic Participation and Perceptions of Body Size and Weight Control in Adolescent Girls: The Role of Sport Types. Sociology of Sport Journal, 23 (3), 248-272.

D'Amico, F. \& Weinstein, L. (Eds.). (1999). Gender Camouflage: Women and the U.S. Military. New York and London: New York University Press.

Donovan, J. (1987). Feminist Theory: the Intellectual Traditions of American Feminism. New York: Ungar.

Douglas, D. (2005). Venus, Serena, and the Women's Tennis Association: When and Where "Race" Enters. Sociology of Sport Journal, 22(3), 256-282.

Douglas, D. \& Jamieson, K. M. (2006). A Farewell to Remember: Interrogating the Nancy Lopez Farewell Tour. Sociology of Sport Journal, 23(2), 117-141.

Duggan, L. \& Hunter, N. D. (1995). Sex Wars. New York: Routledge.

Fausto-Sterling, A. (1992). Myths of Gender: Biological Theories about Women and Men. New York: Basic Books.

Fausto-Sterling, A. (2000). Sexing the Body: Gender Politics and the Construction of Sexuality. New York, N.Y: Basic Books.

Feinman, I. (2000). Citizenship Rites: Feminist Soldiers and Feminist Anti-Militarists. New York and London: New York University Press.

Foucault, M. (1982). The Subject and Power. In H.L. Dreyfus \& P. Rabinow (eds.), Michel Foucault: Beyond Structuralism and Hermeneutics (pp. 208-229). Brighton, Harvester.

Fraser, N. (2008). Emancipation is not an All or Nothing Affair. Eurozine, January 8, pp. 1-12.

Fraser, N. (2007). Feminist Politics in the Age of Recognition: A Two-Dimensional Approach to Gender Justice. Studies in Social Justice, 1 (1), 23-35.

Fraser, N. (2000). Rethinking Recognition. New Left Review, 3, 107-120.

Fraser, N. (1997). Justice Interruptus: Critical Reflections on the "Postsocialist" Condition. New York and London: Routledge.

Fraser, N. (1993). Rethinking the Public Sphere: A Contribution to the Critique of Actually Existing Democracy. In B. Robbins (ed.), The Phantom Public Sphere (pp 1-32). Minneapolis: University of Minnesota Press.

Fraser, N. (1987). What's Critical about Critical Theory? The Case of Habermas and Gender. In S. Benhabib \& D. Cornell (eds.), Feminism as Critique (pp. 31-55). Minneapolis: University of Minnesota Press.

Griffin, P. (1998). Strong Women, Deep Closets: Lesbians and Homophobia in Sport. Champaign, Illinois: Human Kinetics Press.

Hall, M. A. (2002). The Girl and the Game. Toronto: Broadview Press.

Haraway, D. (1991). Simians, Cyborgs and Women: The Reinvention of Nature. New York: Routledge.

Haraway, D. (1997).Modest_Witness@Second_Millenium.Femaleman $@$ Meets_OncoMouse ${ }^{\mathrm{TM}}$.

Feminism and Technoscience. New York: Routledge.

Heywood, L. \& Dworkin, S. (2003). Built to Win: The Female Athlete as Cultural Icon. Minneapolis, MN: University of Minnesota Press.

Hines, S. (2005). I'm A Feminist But...Transgender Men and Women and Feminism. In J. Reger (ed.), Different Wavelengths: Studies of the Contemporary Women's Movement (pp. 57-77). New York and London: Routledge.

Hoberman, J.M. (1997). Darwin's Athletes: How Sport Has Damaged Black America and Preserved the Myth of Race. Boston: Houghton Mifflin.

Jeffreys, S. (2007). Double Jeopardy: Women, the US Military and the War in Iraq. Women's Studies International Forum.Retrieved January 24 from www.sciencedirect.com 
Kane, M. J. (2008). Media Representations of Female Athletes: The Good, the Bad, and the Dangerous. Retrieved from http://cehd.umn.edu/tuckercenter/projects/default.html\#Mediarepresentations

Kane, M. J. (1995). Resistance/Transformation of the Oppositional Binary: Exposing Sport as a Continuum. Journal of Sport and Social Issues, 19 (2), 191-218.

Kay, T. (2003). Sport and Gender. In B. Houlihan (ed.), Sport and Society: A Student Introduction (pp. 89-104). London: Sage.

Kirby, S. \& Huebner, J. (2002). Talking about Sex: Biology and the Social Interpretations of Sex in Sport. Canadian Woman Studies, 21 (3), 36-43.

Lapchick, R.E. (2001). Smashing Barriers: Race and Sport in the New Millennium. Lanham, MD: Madison Books.

Lemert, C. (Ed.). (1999). Social Theory: The Multicultural and Classic Readings. Boulder, CO: Westview Press.

Lenskyi, H. (2003). Out on the Field: Gender, Sport and Sexualities. Toronto: Women's Press.

Madsen, D. L. (2000). Feminist Theory and Literary Practice. London: Pluto Press.

Matthews, B. \& Beaman, L. (2007). Exploring Gender in Canada. Toronto: Pearson-Prentice Hall.

McDonagh, E. \& Pappano, L. (2008). Playing With The Boys: Why Separate is not Equal in Sports. New York: Oxford University Press.

Messner, M.A., Dunbar, M. and Hunt, D. (2000). The Televised Sports Manhood Formula. Journal of Sport \& Social Issues, 24(4), 380-394.

Miller, T., Lawrence, G., McKay, J. \& Rowe, D. (2001). Globalization and Sport. London: Sage.

Millward, R. (2008). Wie Scrutinized for Trying Men's Tour Again. The Globe and Mail. July 30, S8.

Morris, A. (1984). The Origins of the Civil Rights Movement: Black Communities Organizing for Change. New York and London: The Free Press.

Mosse, G. L. (1988). Nationalism and Sexuality: Middle Class Morality and Sexual Norms in Modern Europe. Madison: University of Wisconsin Press.

Pateman, C. (1989). The Disorder of Women: Democracy, Feminism and Political Theory. Cambridge: Polity.

Pateman, C. \& Mills, C.W. (Eds.). (2007). Contract and Domination. Cambridge, UK: Polity.

Paxton, P. \& Hughes, M. M. (2007). Women, Politics, and Power: a Global Perspective. Thousand Oaks, CA: Pine Forge Press.

Pronger, B. (1990). The Arena of Masculinity: Sports, Homosexuality, and the Meaning of Sex. New York: St. Martin's Press.

Pronger, B. (1999). "Outta my Endzone: Sport and the Territorial Anus," Journal of Sport \& Social Issues, 23(4), 373-389.

Rawls, J. (1999). A Theory of Justice. Cambridge, Massachusetts: Belknap Press of Harvard University Press.

Reger, J. (2005). Different Wavelengths: Studies of the Contemporary Women's Movement. New York: Routledge.

Ring, J. (2008). Stolen Bases: Why American Girls Don't Play Baseball. Chicago, IL: University of Illinois Press.

Ritchie, I. (2003). Sex Tested, Gender Verified: Controlling Female Sexuality in the Age of Containment. Sport History Review, 34 (1), 80-98.

Roberts, S. (2005). Why Women Choose to Battle Men: Because that's Where the Money Is, The New York Times, June 5, Section 8, Page 7.

Rothblatt, M. (1995). The Apartheid of Sex: A Manifesto on the Freedom of Gender. New York: Crown Publishers.

Robinson, L. (2002). Black Tights: Women, Sport, and Sexuality. Toronto: Harper Collins.

Solaro, E. (2006). Women in the Line of Fire: What You Should Know About Women in the Military. Emeryville, CA: Seal Press. 
Spencer, D. (2008). Wickenheiser Signs on to Suit Up for Swedish Men's Team. The Globe and Mail, July 23, page S5.

Stead, D. (2003). Sport and the Media. In B. Houlihan (ed.), Sport and Society: A Student Introduction (pp. 184-200). London: Sage.

Suggs, W. (2005). A Place on the Team: the Triumph and Tragedy of Title IX. Princeton, N.J: Princeton University Press.

Sykes, H. (2006). Transsexual and Transgender Policies in Sport. Women in Sport and Physical Activity Journal, 15 (1), 3-13.

Teetzel, S. (2006). On Transgendered Athletes, Fairness and Doping: An International Challenge. Sport in Society, 9 (2), 227-251.

Theberge, N. (2000). Higher Goals: Women's Ice Hockey and the Politics of Gender. Albany, New York: SUNY Press.

Travers, A. (2006). Queering Sport: Lesbian Softball Leagues and the Transgender Challenge. International Review for the Sociology of Sport, 41 (3-4), 431-446.

Van Sterkenburg, J. \& Knoppers, A. (2004). Dominant Discourses about Race/Ethnicity and Gender in Sport Practice and Performance. International Review for the Sociology of Sport, 39(3), 301-321.

Vincent, J. (2004). Game, Sex, and Match: the Construction of Gender in British Newspaper Coverage of the 2000 Wimbledon Championships. Sociology of Sport Journal, 21 (4), 435-456.

Ware, V. (1992). Beyond the Pale: White Women, Racism and History. London: Verso.

Walton, T. \& Butryn T. (2006). Policing the Race: U.S. Men's Distance Running and the Crisis of Whiteness. Sociology of Sport Journal, 23 (1), 1-28.

Whitson, D. \& Gruneau, R. (2006). Artificial Ice: Hockey, Culture and Commerce. Peterborough, Ontario: Garamond Press.

Wolf, N. (1992). The Beauty Myth: How Images of Beauty Are Used against Women. New York: W. Morrow.

Young, I. M. (2000). Inclusion and Democracy. Oxford and New York: Oxford University Press.

Yurako, K. (2002). Title IX and the Problem of Gender Equality in Athletics. Gender Issues. 20 (2/3), 65-80.

Zirin, D. (2007). Welcome to the Terrordome: The Pain, Politics and Promise of Sports. Chicago, Illinois: Haymarket Books 